\title{
The Correlation of Dermatoglyphic Pattern and Immunoglobulin-E serum Levels in People with Atopic Stigmata
}

\author{
Gardenia Akhyar ${ }^{1}$, Ennesta Asri ${ }^{2}$, Rina Gustia ${ }^{3}$ \\ (dr.gardenia94@gmail.com ${ }^{1}$, ennestasri@gmail.com ${ }^{2}$, rinagustia@gmail.com ${ }^{3}$ )
}

Department of Dermatology and Venereology, Medical Faculty of Andalas University/ Dr. M. Djamil Hospital, Padang - Indonesia

\begin{abstract}
Atopy stigmataoccurin individual with hypersensitivity state that is related with the formation of excessive serum IgE thatdetermined by genetic factor. The dermatoglyphic pattern is formed prenatally and remains unchanged throughout the lifetime. It can help to establish the diagnosis of genetic diseases, such as stigmata of atopy. The aim of this study was to determine the specific pattern of dermatoglyphics in patient with stigmata of atopy and to determineits relationship with serum IgE level. This study was an analytical study with a cross-sectional design. The dermatoglyphic patterns of patients with atopic stigmata were collected.Weexaminedthe pattern of loop, whorl or arc on right and left hand. IgE levels were measured with Elisa method. Data were analyzed statistically. Loop is the most frequent dermatoglyphic patternon right and left hand $(58.52 \% ; 63.70 \%)$ followed by whorl $(31.85 \% ; 28.89 \%)$ and arc $(9.63 \% ; 7.41 \%)$. There was no relationship between the pattern of dermatoglyphics andserum IgElevel ( $>0.05$ ). Pattern of loop, whorl and arc is not different between atopic and non atopic group. This pattern classificationis the most frequently usedindermatoglyphic. Others pattern such as total pattern count, cores, radiant, atd angle, a-b ridgecanbe used to determine the specific pattern in specific diseases. Apart from genetic factor, dermatoglyphic pattern are also influenced by ethnic and geographical factor. There was no specific dermatoglyphicpattern in an atopic patients and this pattern was also not associated with serum IgE level.
\end{abstract}

Keywords: Atopic, Dermatoglyphics, Genetic, Hypersensitivity

\section{Introduction}

Dermatoglyphics is the scientific study of the shape or pattern of fingerprints by assessing tendril at the tips of the fingers, palms, soles of the feet, and toes. ${ }^{1}$ Dermatoglyphic patterns are formed from the beginning of embryonic development starting from 13 weeks to 24 weeks of pregnancy. ${ }^{2}$ The formation of this dermatoglyphic pattern is polygenic which is influenced by many genes. ${ }^{3}$ Dermatoglyphics that are formed are permanent for lifetime and will not change after the baby is born unless an accident occurs that results in damage to the skin, such as injury, burn or disease. ${ }^{4,5}$

Fingerprints can stay on the surface by transferring oil or amino acids, substances that are on the fingers such as paint or blood, or by giving certain materials that will be printed to the surface so that fingerprint patterns can be read and studied. ${ }^{6}$

Patients with hereditary disease, especially the diseases caused by chromosome aberration, will have a distinctive dermatoglyphics. ${ }^{7}$ Fingerprints can be used to identify people with genetic predispositions for the development of certain diseases ${ }^{5,8}$.

In general, atopic dermatitis, allergic rhinitis, allergic conjunctivitis and bronchial asthmadevelop chronically and recidively. These diseases cause high morbidity and greatly affect the patient'squality of life. The incidence of these diseases has recently been reported to increase along with the increase of exposure to allergen material ${ }^{9}$. 
In individuals with atopic history, there is a tendency for being hypersensitive to some ingredients (generally proteins) commonly found on a daily basis such as dust, food or plant powders although only in small amounts or doses. The procedure of allergen identification is quite difficult, especially in children who have not been able to cooperate ${ }^{10}$.

The underlying pathogenesis of this hypersensitivity is the formation of excessive IgEin response to allergen ingredients. In the late 1960s, Ishizaka and Ishizaka discovered an increased type of IgE immunoglobulin in patients with atopy, and the increase is mainly triggered by environmental allergens ${ }^{11}$.

This tendency to hypersensitivity is genetic. Genes that play a role in theatopy development (hyper-IgE responsiveness) are thought to be found on chromosomes that control $\operatorname{IgE}$ production, namely chromosome $11 \mathrm{q} 13$ which encodes the $\beta$ subunits of type 1 Fc receptor of $\operatorname{IgE}^{12,13}$.

The aim of this study was to determine the specific pattern of dermatoglyphics in patient with stigmata of atopy and to determine its relationship with serum IgE level

\section{Methods}

This research was an analytical study with a cross sectional study design. Samples were patients who came to the Dr. M. DjamilHospital in Padang who had atopic stigmata history (atopic dermatitis, allergic rhinitis, urticaria, allergic conjunctivitis) with inclusioncriteria:age $>18$ years old and were willing to participate in this research. Exclusion criteria: samples with dermatology disorders in the palms that make it difficult to read fingerprints; not suffering from other diseases, such as lupus, psoriasis, rheumatoid arthritis, and other genetic diseases. The selection of research subjects was carried out by consecutive sampling, which is the selection of subjects to obtain a sufficient number of samples.

Examination of serum Ig-E levels by using the Elisa method was carried out in the Biomedical Laboratory of Faculty of Medicine, Andalas University.

The retrieval of the dermatoglyphic pattern wasconducted by using the Cumin and Midlo methods. First, the patients appliedthe ink (Daito®) thinly and evenly on the glass plate.After that, the patients would press and roll over their fingers on the glass plate in a one-way movement.Then, the patterns of the fingers were affixed to white paper with a little samedirectional compression so that the dermatoglyphicpattern would be printed in the paper. Finally, the type of dermatoglyphic pattern could be determined ${ }^{14}$.

Data processing and analysis were computerized by using SPSS (Statistical Program for Social Sciences) and presented in tables. The analysis of the dermatoglyphic pattern and its correlation with the IgE level were conducted by using Mann-Whitney U testtest with significance value (p) $<0.05$. This study was approved by the Ethics Committee of the Medical Faculty of Andalas University.

\section{Results}

This study was conducted on 27 samples from each of the following groups, namely the atopic stigmata group and the non-atopic group. The results of the study were presented in the form of tables.

Table 1. Distribution of samples by age group

\begin{tabular}{cccc}
\hline Age Group & Atopic & Non-Atopic & Total \\
\hline $20-30$ years & $19(70.36 \%)$ & $18(66.67 \%)$ & $37(68.52 \%)$ \\
$30-40$ years & $3(11.13 \%)$ & $5(18.51 \%)$ & $8(14.81 \%)$ \\
$>40$ years & $5(18.51 \%)$ & $4(14.82 \%)$ & $9(16.67 \%)$ \\
\hline
\end{tabular}




\begin{tabular}{cccc}
\hline Total & $27(100 \%)$ & $27(100 \%)$ & $54(100 \%)$ \\
\hline
\end{tabular}

Most samples inatopic and non-atopic groups were 20-30 years old. The age group of 20-30 years old is a relative high-risk age group for suffering from atopic occurrence, because there are more possibilities to be exposed to the causative allergens.

Table 2. Dermatoglyphic tendril patterns in atopic and non-atopic groups

\begin{tabular}{lccccc}
\hline \multirow{2}{*}{ Tendril } & \multicolumn{2}{c}{ ATOPIC } & \multicolumn{2}{c}{ NON-ATOPIC } & \\
\cline { 2 - 5 } Pattern & Right hand & Left hand & Right hand & Left hand & Total \\
\hline Loop & $79(58.52 \%)$ & 86 & 79 & 85 & 329 \\
& & $(63.70 \%)$ & $(58.52 \%)$ & $(62.96 \%)$ & $(60.93 \%)$ \\
Whorl & 43 & 39 & 52 & 45 & 179 \\
& $(31.85 \%)$ & $(28.89 \%)$ & $(38.52 \%)$ & $(33.33 \%)$ & $(33.15 \%)$ \\
Arc & 13 & 10 & 4 & 5 & 32 \\
& $(9.63 \%)$ & $(7.41 \%)$ & $(2.96 \%)$ & $(3.71 \%)$ & $(5.92 \%)$ \\
Total & 135 & 135 & 135 & 135 & 540 \\
& $(100 \%)$ & $(100 \%)$ & $(100 \%)$ & $(100 \%)$ & $(100 \%)$ \\
\hline
\end{tabular}

Table 2 shows that the loop pattern on right and left hand had the highest percentage in both of the atopic and non-atopic groups with $58.52 \%$ on the right handand $63.70 \%$ on left hand of the atopic group and $58.52 \%$ on the right hand, $62.96 \%$ on the left hand in non atopic group, followed by the whorl and arc patterns. There was no significant difference between the forms of dermatoglyphicstendrilpattern in atopic and non-atopic group $(\mathrm{p}>0.05)$

Table 3. The relationship between dermatoglyphic tendril pattern and IgE levels in atopic and non-atopic groups

\begin{tabular}{cccccc}
\hline Tendril & \multicolumn{2}{c}{ Atopic } & \multicolumn{2}{c}{ Non-Atopic } & P \\
\cline { 2 - 5 } Pattern & $\begin{array}{c}\text { High } \\
\text { Ig E }\end{array}$ & Normal IgE & $\begin{array}{c}\text { High } \\
\text { IgE }\end{array}$ & $\begin{array}{c}\text { Normal } \\
\text { IgE }\end{array}$ & \\
\hline Loop & 101 & 64 & 20 & 144 \\
& $(37.42 \%)$ & $(23.70 \%)$ & $(7.41 \%)$ & $(53.33 \%)$ & \\
Whorl & 45 & 37 & 22 & 75 & $>0.05$ \\
& $(16.67 \%)$ & $(13.70 \%)$ & $(8.15 \%)$ & $(27.78 \%)$ & \\
Arc & 14 & 9 & 4 & 5 & \\
& $(5.18 \%)$ & $(3.33 \%)$ & $(1.48 \%)$ & $(1.85 \%)$ & \\
Total & & $\mathbf{2 7 0}$ & & $\mathbf{2 7 0}$ & \\
\hline
\end{tabular}

Table 3 shows that there was no association between the form of dermatoglyphic tendril pattern and IgE levels. The loop form was the most common dermatoglyphic tendril pattern in atopic group. In non-atopic group with high IgE levels, the most commonly found tendrilpattern are the whorl form. Until now, we have not found another study that examined the relationship between the form of dermatoglyphic tendril pattern and the IgE levels.

\section{Discussion}

Research on the pattern of dermatoglyphics in the field of dermatology is still limited. Until now, we have not found another study about dermatoglyphic patterns in patients with atopic 
stigmata that have been associated to theIg-E levels. Thus, the data from this study can only be compared with the dermatoglyphic patterns from other diseases.

This study found that the loop pattern was the most common pattern in the atopic and nonatopic groups. In 2005, Gusfirman et al. in Padang also demonstrated the loop pattern as the most commonly found tendril pattern in students from the Minangkabau ethnic group based on blood type. Furthermore, the study of Amadino A et al. in Padang in 2015 have also found that the loop pattern as the most common dermatoglyphic pattern. However, another study has come with a different result that the most common tendril pattern in Minangkabau students in Madiun in 2017 was the whorl form. The study only found the whorl and loop forms as much as 70:301518 .

The variations of dermatoglyphic patterns in various cases of diseases other than those caused by genetic factors are also influenced by geographical and ethnic factors. The study by Hidayati F demonstrated that the loop type was the dominant type on Javanese ethnic group whereas the whorl type was the most common type on Papuans ethnic group ${ }^{19}$.

The dermatoglyphic pattern can be assessed from the fingertips and the palms. The most commonly used classification is the classification of Cumin and Midlo which divides the dermatoglyphicsinto 3 main patterns, namely loop, whorl, and arc. There are other patterns that can be assessed from the fingertips, such as the number of tendrils, triradii, cores, and radiant. Meanwhile, form the palm, we can also examine the angle of ATD, a-b ridge count, or assessing the Dankmeijer index, Furuhata index, and pattern intensity index. ${ }^{20}$

\section{Conclusion}

The most commonly found dermatoglyphictendril pattern was the loop form. There was no significant correlation between the dermatoglyphic tendril pattern and the IgE levels in people with atopic history.

\section{References}

1. Bhat GM, Mukhdoomi MA, Shah BA, Ittoo MS. Dermatoglyphics: in health and disease - areview. Int J Res Med Sci.2(1):31-7 (2014)

2. Brunson EK, Hohnan DJ, Gioas CM. ATD. Reliability of the angle in dermatogyphic analysis.Coll Antropol. 39(3):797-800 (2015)

3. Wu LC, Zarrin AA. The production and regulation of IgE by the immune system. Nat REv Immunol.14(4):247-59(2014) Dehankar R, Bhakare U, Ksheersagar D. The study of palmar dermatoglyphics in psoriasis. Int J Phhand Bio Sci. 2013;4(1):554-61.

4. Elizabeta D, Lazaroa D, Zafira B, TrpkovskaB, Bojadzieva B. Dermatoglyphics in patients with psoriasis. Acta Morphol.10(1):15-8 (2013)

5. Esparza-Gordillo J, Weidinger S, Foelster-Holst RR, Ruether A. A common variant on chromosome 11q13 is associated with atopic dermatitis. Nat Genet.41(5):596-601 (2009)

6. GibbsRC.Fundamental of dermatoglyphics.Arch Dermatol.96(6):721-5 (1967)

7. Gupta RK, Gupta AK. New, easy and effective method to take dermatoglyphic prints. Natl J Med Res.3(1):45-7 (2013)

8. Ghaderi R, Sharifzadeh G, Monnazah E, Ghamari M. Quantitative and qualitative dermatoglyphic pattern in patiens with atopic eczema, vitiligo and acne vulgaris. J Birjand Univ Med Sci.20(3):271-8 (2013)

9. Haber R, Helou J, Korkomaz J, Habre M, Ghanem A, Tomb R. Absence of fingertips with focus on dermatological etiologies: national survey and review.Clin Dermatol.3(1):21-6 (2015) 
10. Larsen FS. Genetic aspects of atopic eczema. In : Ruzicka T, Ring J, Przybilla B editors. Handbook of atopic eczema. $1^{\text {st }}$ edition. New York. Springer:19-26 (1991)

11. O'Regan Gm, Campbell LE, Cordell HJ Irvine AD, McLean WH, Brown SJ. Chromosome 11q13.5 variant associated with childhood eczema : an effect supplementary to filaggrin mutations. J Allergy Clin Immunol.125(1):170-4 (2010)

12. Jones dan Christopher. Fingerprint patterns probably inherited. Cheirological Society1993)

13. Praba L, Thenmozhi RT. A short review on dermatoglyphic. J Pharm Sci \& Res. 6(4): 200-2 (2014)

14. Gusfirman T, Megahati S.RRP, Wati M. Dermatoglifi ujung jari dan telapak tangan berdasarkan golongan darah sistem ABO pada mahasiswa biologi bersuku Minang di STKIP PGRI Sumatera Barat. Jurnal Ilmiah Mahasiswa. http://jim.stkip-pgrisumbar.ac.id

15. Amadino A, Susanti R, Afriant R. Gambaran pola dermatoglifi pada ujung jari tangan penderita penyakit hipertensi esensial di kota Padang tahun 2014. Jurnal Kesehatan Andalas.;3(1) 100-103 (2014)

16. Purbasari K, Sumadji AR. Variasi pola sidik jari mahasiswa berbagai sukubangsa di Universitas Katolik Wydya Mandala Madiun. ProceedingSeminar Nasional SIMBIOSIS II, Madiun, 30 September. 410-21(2017)

17. Hidayati F. Variasi pola sidik jari populasi Jawa dan Papua. Antropology Unair dot Net.; 7(1); 30-41 (2015)

18. Gradiser M, Osvatic MM, Dilber D, Curcic IB. Assesment of environmental and hereditary influence on development of pituitary tumors using dermatoglyphic traits and their potential as screening marker. Int J Environ Res Public Health. 13: 330-9 (2016)

19. Kaur J, Batra APS. Role of dermatoglyphics in medical disorders. Indian J of Fund and Appl Life Sci.3(3):536-9 (2013)

20. Kapoor N, Badiye A. Digital dermatoglyphics; A study on Muslim population from India. Egyption J. of Forensicc Sci. 5(3).90-95 (2015) 